\title{
Prenatal development of the sound transmitting apparatus in different embryonic stages of Malpolon monsspesulanus (squamata-serpentes)
}

\author{
A. I. Dakrory ${ }^{a, b}$, A. M. Abu-Taira ${ }^{a}$, E. Y. Salah EL-Din ${ }^{a^{*}}$ and Y. B. Mohamed ${ }^{a}$ \\ ${ }^{a}$ Department of Zoology, Faculty of Science, Cairo University - CU, El-Gammaa, 12613, Cairo, Giza, Egypt \\ ${ }^{b}$ Biology Department, Faculty of Science, Taif University, 888, Hawiyah, 21944, Taif, Kingdom of Saudi Arabia \\ *e-mail: e_youssri@yahoo.com
}

Received: March 3, 2017 - Accepted: May 30, 2017 - Distributed: November 30, 2018

(With 10 figures)

\begin{abstract}
The developmental investigation of sound transmitting apparatus is important in understanding the ontogenetic processes behind morphological diversity. The development of sound conducting apparatus was studied in Montpellier snake; Malpolon monspessulanus at $6.5,7.2,8.3$ and $9.3 \mathrm{~cm}$ total body lengths using light microscopy study. The columella auris firstly appeared as undifferentiated rod shape mesenchymal cells. As the growth proceeded, it chondrified and differentiates into two main parts. In addition, the viscerocranium components which participate in formation of sound transmitting apparatus undergo critical organization. In more advanced stages, procartilagenous stylohyal chondrified and fuse with the well organized quadrate. These data considered as a base for functional and molecular mechanisms of sound transmitting apparatus studies and identification of diseases that may infect them.
\end{abstract}

Keywords: columella auris, quadrate, stylohyal, tympanic cavity.

\section{Desenvolvimento pré-natal do aparelho transmissor de som em diferentes estágios embrionários de Malpolon monsspesulanus (Squamata-serpentes)}

\begin{abstract}
Resumo
A investigação do desenvolvimento de equipamentos de transmissão de som é importante na compreensão dos processos ontogenéticos atrás diversidade morfológica. O desenvolvimento de aparelhos de som realização foi estudada em Montpellier cobra; Monspessulanus Malpolon em 6.5, 7.2, 8.3 e $9.3 \mathrm{~cm}$ corporal total utilizando comprimentos de estudo de microscopia de luz. $\mathrm{O}$ auris columelar em primeiro lugar apareceu como células mesenquimais forma haste indiferenciada. Como o crescimento passou, ele chondrified e diferencia em duas partes principais. Além disso, os componentes viscerocrânio que participam na formação do aparelho de transmissão de som submeter a organização crítico. Em estágios mais avançados, stylohyal procartilagenous chondrified e se fundem com o quadrado bem organizado. Estes dados considerados como uma base para os mecanismos funcionais e estudos moleculares do aparelho de transmissão de som e identificação de doenças que podem infectar-los.
\end{abstract}

Palavras-chave: auris columella, quadrate, stylohyal, cavidade timpânica.

\section{Introduction}

In most tetrapods, the tympanic middle ear provides impedance matching between the air and inner ear fluids and enhances pressure hearing in air. Also, the evolution of the middle ear components have played an important role in solving this problem of impedance mismatch in the evolutionary transition from aquatic habitat to land (Christensen et al., 2012). Although, the importance of middle ear in hearing process both of Christensen et al. (2015) and Christian et al. (2015) reported that, the terrestrial adult salamanders, the fully aquatic juvenile salamanders and even lung fish which are completely not adapted to aerial hearing were able to detect air borne sound without having a tympanic middle ear. In addition, snakes cannot hear. This presumption is supported by the fact that snakes have neither tympanum nor eustachian tube, and the stapes whose proximal end rests in the vestibular window and its distal end attached to the quadrate bone on which the lower jaw swings (Young, 2003; Friedel et al., 2008; Scanferla and Bhullar, 2014; Dowling, 2015) and that scientific evidence of snakes responding to sound is rare. Snakes do, however, possess an inner ear with a functional cochlea and with poorly developing middle ear components. The vibrations from the prey footsteps pass underneath both sides of the jaw travel through the snake's head through two bones - the quadrate and stapes - and then stimulate the cochlea (Zyga, 2008; Christensen et al., 2012; Knight, 
2012). The special characterization in snake skull allows to them to swallow very large meals and allowed hearing process to develop (Friedel et al., 2008; Thewissen et al., 2008).

Versluys (1903) studies the chondrification of the columella auris in Lacertilia and Rhynchocephalia. Brock (1929) and Hernández-Jaimes et al. (2012), in their studies on the development of the skulls of Leptodeira hotamboia and Ptychoglossus bicolor, respectively referring the development of columella auris in relation to fenestra ovalis of otic capsule and quadrate. In the lizards, De Beer (1937) studies the development of columella auris in relation to the auditory capsule during its investigation to vertebrate skull development. In addition, Kamal and Hammouda (1965) study the development of the columella auris in Psammophis sibilans. El-Toubi et al. (1973a, b), study the developmental of chondrocranium of Malpolon monspessulanus ponting to the columella auris organization. Goldby (1925), study the development of the columella auris in Crocodiliu spalustris and Alligator mississipiensis. Kundrát (2009) investigate the morphogenesis of the crocodilian and avian columellaauris using Alligator and Struthio as models for this study. Köppl et al. (2013), mention that the columella auris originate from the second gill arch in the primitive vertebrates.

The development of stylohyal (a segment in the hyoidean arch) and its relation to columella auris and quadrate were estimated in Lacertilia (Parker, 1879), in Vipera bervus (Möller, 1905), in Trigonocephalus (Okajima, 1915), In Leptodeira hotamboia (Brock, 1929), in lizard (De Beer, 1937).

Despite the fact that the previous works present a good survey of the development of the Ophidian sound transmitting apparatus, it cannot be assumed that no further beneficial work remains to be done on this topic. Some theoretical questions still depend for satisfactory settlement upon the investigation of a big collection of successive developmental stages of different species. Thus, it was found useful to make a detailed study on the development of the sound transmitting apparatus of one of the Egyptian Colubrid snake, Malpolon monspessulaus. Our developmental series furnishes on excellent degree of resolution, permitting not only a comprehensive description of the sequences of the sound transmitting apparatus development of Malpolon monsspesulanus, but also comments on some specific aspects of its embryology.

\section{Material and Methods}

Malpolon (Coelopeltis) monspessulana belongs to the family Colubridae (Bernhard, 1971) which includes the majority of living snakes. Numbers of pregnant females were collected from the field during May and June. At the end of June, the pregnant females laid their eggs freely on the sand. The eggs, whitish yellow, and elliptical in shape, were incubated in damp soil at room temperature. The average number of days of the period of incubation is 63. Thus it was possible to collect a set of embryos of different stages of Malpolon monsspesulanus. The embryos were removed from their shells, and only those which were living and healthy were fixed in aqueous Bouin's fixative for 24-48 hours according to the size of the embryos and used. For comparative purposes, therefore, measurements of total body length are used, and authors are driven to adopting the total body length as their standard of comparison. The different stages are described in this paper are listed below in Table 1.

Large four embryos were treated with EDTA solution for decalcification. Taken time for decalcification process ranged from 30 to 40 days depending on the size of the embryo, during which the EDTA solution was changed every 4 days. This was followed by washing the embryos several times with $70 \%$ ethyl alcohol.

Embryos were treated with ascending series of ethyl alcohol and then cleared with xylene. Thereafter, the specimens were embedded in a paraffin wax. This was followed by sectioning embryos transversely at 10 microns thickness using Reichert microtome.

The sections of each specimen were mounted serially on microscopic slides and prepared for staining. The latter was carried out by Haematoxylin (Ehrlich) and counterstained by Eosin to obtain permanent histological preparations.

The sound transmitting apparatus is examined in these sections. Several sections were chosen for photomicrography using Zeiss photomicroscope supplied by Canon digital camera to describe the different developmental changes of the middle ear and its relation to the different neighboring structures.

The work has been carried out in the Department of Zoology (Comparative Anatomy \& Embryology), Faculty of Science, and Cairo University.

\section{Results}

Stage1 (dpo, 20 days; total body length: $6.5 \mathrm{~cm}$; Figures 1, 2)

The columella auris of Malpolon monsspesulanus firstly appears as rod-shaped, undifferentiated mesenchymatous cells (Figures 1, 2, C.A). It appears separated from the boundaries of the auditory capsule (A.C), but both of them are very close to each other. The orientation of columella is oblique; the ventral part of it is directed slightly anteriorly, while the dorsal portion is directed posteriorly. On the ventrolateral wall of the cochlear portion of the auditory capsule, the dorsal portion of the columella auris of this

Table 1. Include number of stages, days post-oviposition, and total body lengths.

\begin{tabular}{ccc}
\hline Stage & $\begin{array}{c}\text { DPO } \\
\text { (days post- } \\
\text { oviposition) }\end{array}$ & $\begin{array}{c}\text { Total body length } \\
\text { (cm) }\end{array}$ \\
\hline 1 & 20 & 6.5 \\
2 & 23 & 7.2 \\
3 & 28 & 8.3 \\
4 & 30 & 9.3 \\
\hline
\end{tabular}

DPO: days post-oviposition. 
stage rest on it (Figure 1). The ventral portion of the columella appears freely (Figure 2). With regards to the viscerocranium components which shares in formation of different structures of the sound transmitting apparatus;

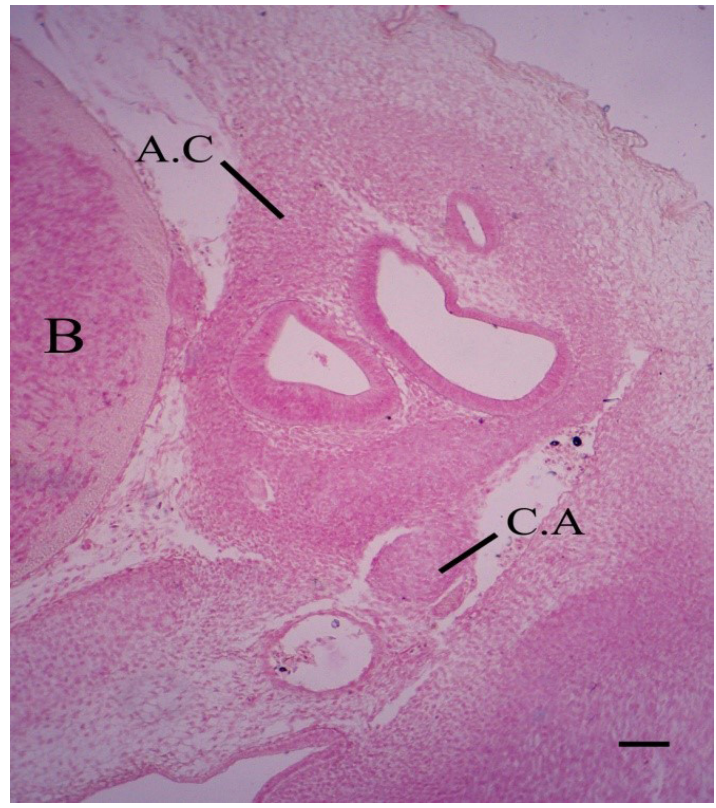

Figure 1. Photomicrograph (H\&E) of a transverse section passing through the auditory region at $6.5 \mathrm{~cm}$ total body length, showing the dorsal portion of undifferentiated mesenchymatous rod shape columella auris (C.A) close to the auditory capsule (A.C). Brain (B). Scale bars, $50 \mu \mathrm{m}$.

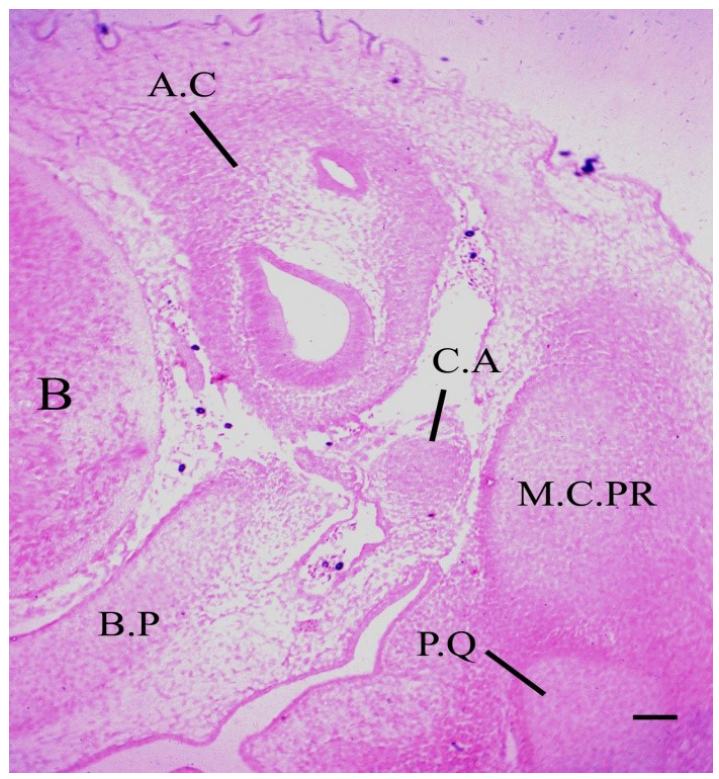

Figure 2. Photomicrograph (H\&E) of a transverse section passing through the auditory region at $6.5 \mathrm{~cm}$ total body length, showing freely ventral portion columella auris, mesenchymatous pterygoquadrate (P.Q), Meckel's cartilage primordium (M.C.PR) and basal plate (B.P). Scale bars, $50 \mu \mathrm{m}$. the ventral component of the mandibular arch (Meckel's cartilage primordium; M.C.PR) and the dorsal component of the mandibular arch (pterygoquadrate; P.Q) appears as mesenchmatous structures (Figure 2). Meckel's cartilages primordia consist of two ramii; each ramus is a cylindrical uniform rod and attains a slight sigmoid curvature. Posteriorly, two ramii of Meckel's primordia are far apart. Anteriorly, they approach each other. However, their anterior tips are separated from each other by a significant distance. Thus no symphysis Meckelii is formed.

Stage2 (dpo, 23 days; total body length: $7.2 \mathrm{~cm}$; Figures 3, 4, 5)

The chief advances which this stage show; the slender rod columella auris shows degrees of chondrification than previous stage. An oval columellar footplate was recessed in the ventrolateral wall of the cochlear portion of auditory capsule (Figure 3 ). The rest of columella (C.A) extends outwards and slightly downwards from the side of the otic capsule during its way to quadrate (Q.C). This way is filled relatively with loose tissue; mostly adipose (Figure 4). The pterygoquadrate (P.Q) is reduced to the quadrate. The latter shows a degree of chondrification and massive appearance, its anterior edge lying on a lower level than its posterior one. The quadrate and the columella are compeletely separate from each other (Figure 5). The two latter structures are very close to each other. Both of them are completely free from the neurocranium and no connection of any kind between the two has ever been traced. The anterior edge of the quadrate articulates with the dorsal margin of the posterior end of Meckel's cartilage (M.C) from the ventral surface of it.

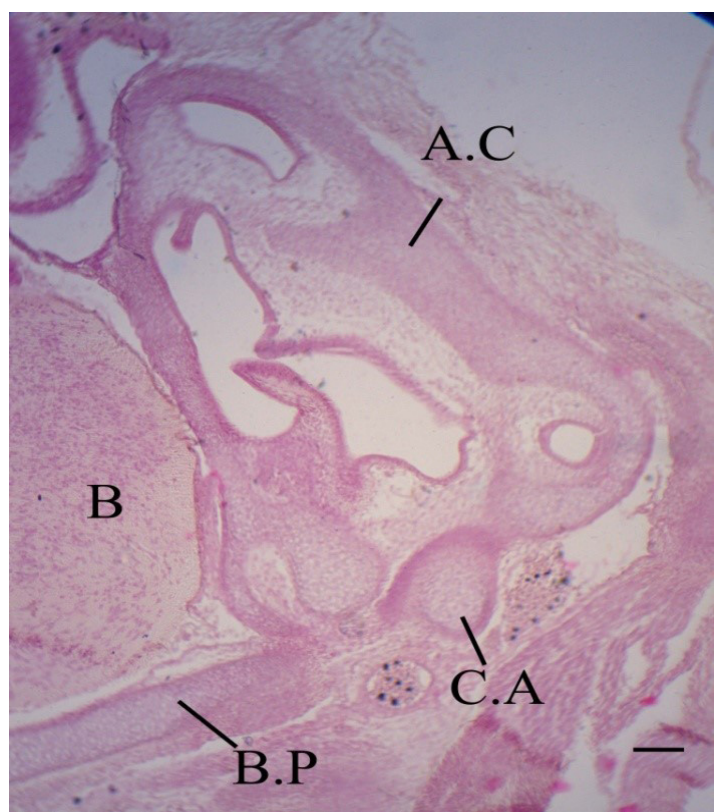

Figure 3. Photomicrograph $(\mathrm{H} \& \mathrm{E})$ of a transverse section passing through the auditory region at $7.2 \mathrm{~cm}$ total body length, showing an oval columellar footplate was dug in the ventrolateral wall of the auditory capsule. Scale bars, $50 \mu \mathrm{m}$. 
Stage 3 (Age 28 days; total body length: $8.3 \mathrm{~cm}$; Figures $6,7,8$ )

The new features have appeared at this stage, the fenestra ovalis (Figure 6, F.OV) attains more developing

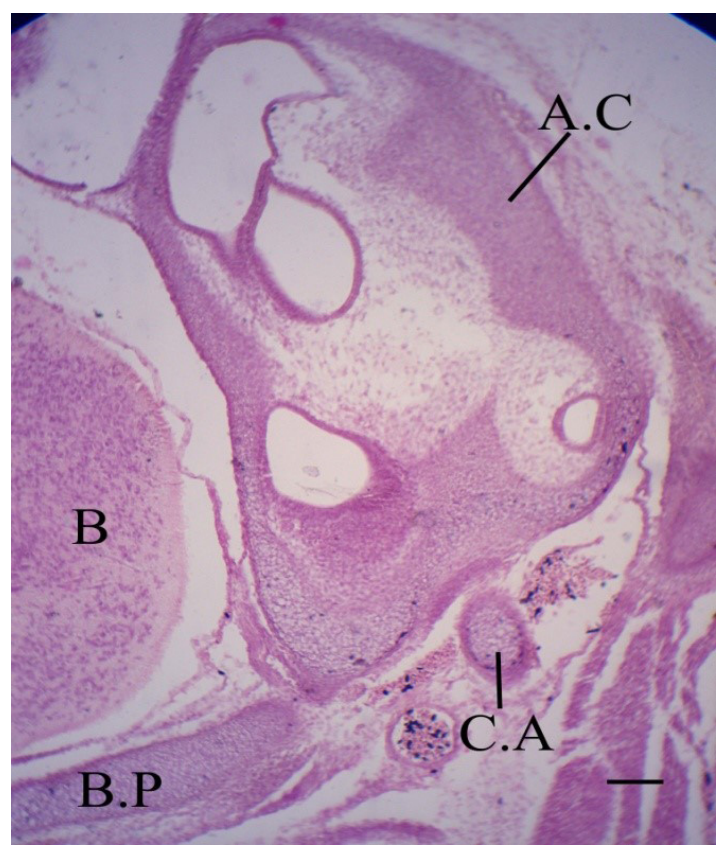

Figure 4. Photomicrograph (H\&E) of a transverse section passing through the auditory region at $7.2 \mathrm{~cm}$ total body length, showing the rest of columella extends outwards and slightly downwards from the side of the otic capsule. Scale bars, $50 \mu \mathrm{m}$.

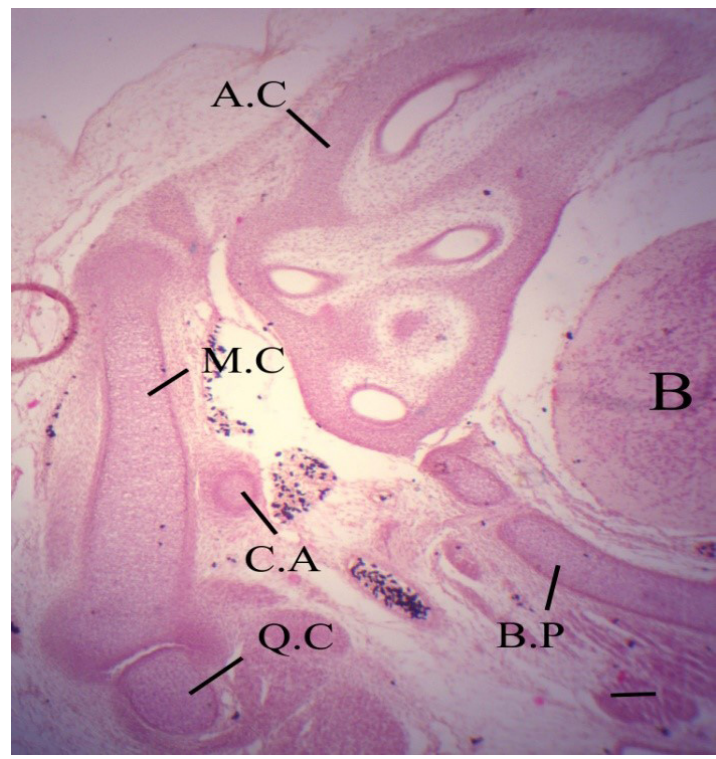

Figure 5. Photomicrograph (H\&E) of a transverse section passing through the auditory region at $7.2 \mathrm{~cm}$ total body length, showing the articulation between the quadrate (Q.C) and Meckel's cartilage (M.C). The quadrate and columella are close to each other. Scale bars, $62.5 \mu \mathrm{m}$. form. It has the form of a large oval foramen situated on the lateral wall of the cochlear portion of the auditory capsule. The columella auris becomes differentiated into the footplate, representing its upper portion, while the shaft, be the rest of the columella. The shaft (SH) is thinner than the foot plate; stapes (ST), its lower edge

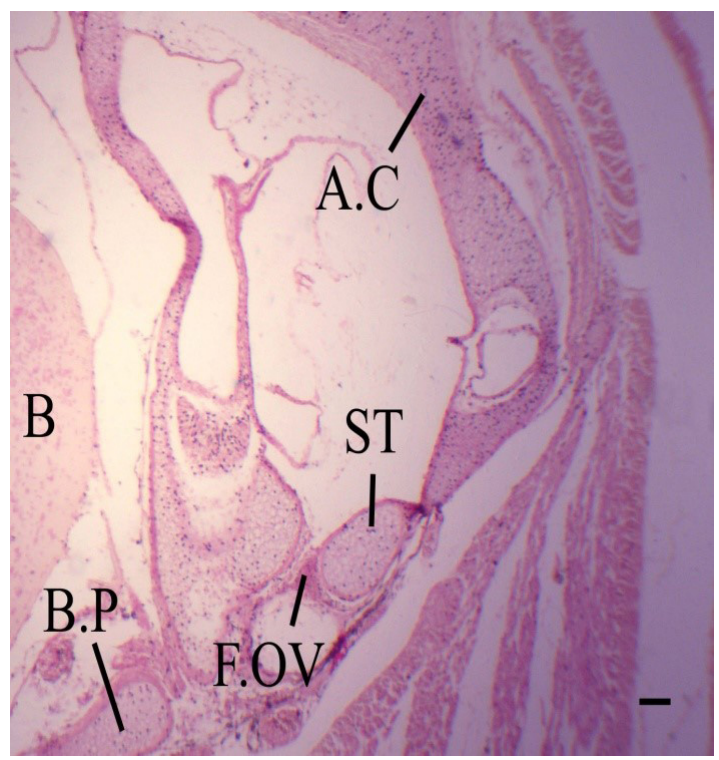

Figure 6. Photomicrograph (H\&E) of a transverse section passing through the auditory region at $8.3 \mathrm{~cm}$ total body length, showing more developing fenestra ovalis (F.OV), with foot plate; stapes (ST) of columella. Scale bars, $75.7 \mu \mathrm{m}$

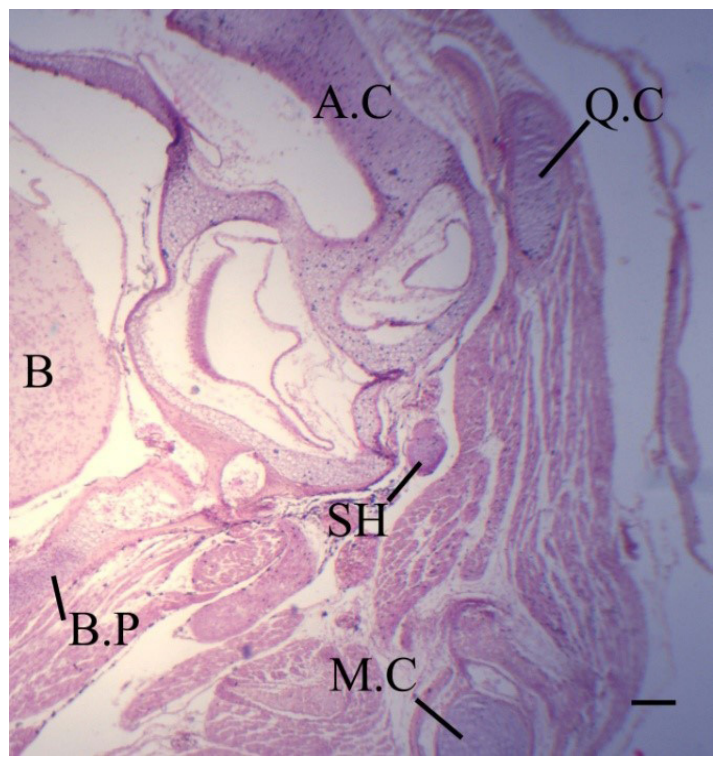

Figure 7. Photomicrograph (H\&E) of a transverse section passing through the auditory region at $8.3 \mathrm{~cm}$ total body length, showing vertically directed shaft $(\mathrm{SH})$ of columella. Quadrate is attach by a highly musculature. Scale bars, $75.7 \mu \mathrm{m}$. 


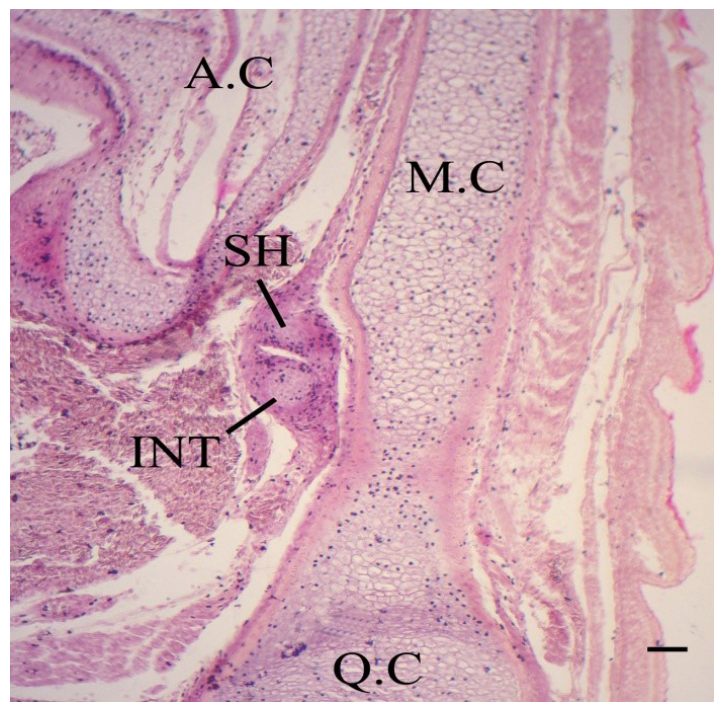

Figure 8. Photomicrograph $(\mathrm{H} \& \mathrm{E})$ of a transverse section passing through the auditory region at $8.3 \mathrm{~cm}$ total body length, showing well chondrified massive quadrate. Procartilagenous stylohyal; intercalare (INT) produced by distal end of columellar shaft. Scale bars, $50 \mu \mathrm{m}$.

lying in close contact with the lower rim of the fenestra ovalis (Figure 6) while its upper edge is free. The shaft of the columella is in the shape of a long rod which pushes itself downwards in a vertical way (Figure 7). mesenchymatous cells (procartilagenous stylohyal; intercalare) are produced by the distal end of the shaft (Figure 8, INT, SH). These cells are connected with the posteromedial projection of the quadrate.

In the present stage, the quadrate (Figure 8) becomes massive and well chondrifies. The anterior half of it lies lateral to the basal plate (Figure 7, B.P); its posterior half lies lateral to the columella and the auditory capsule (Figure 8). The quadrate lies in the same straight line with Meckel's cartilage. Also, there is a posterior dragging of the quadrate cartilage. This shift is affected by the posterior extension of Meckel's cartilage. So the quarate - Meckel's joint appears in posterior position than before. In addition, quadrate is characterized by highly musculature associate with it than previous stage (Figure 7).

Stage 4 (dpo 30 days; total body length: $9.3 \mathrm{~cm}$; Figures 9, 10)

The new features have appeared at this stage, the fenestra ovalis (Figure 9, F.OV) which lies on the lateral wall of the posterior part of the cochlear portion of auditory capsule is more or less circular in outline, and is enlarged during development. It is occluded by the stapes; foot plate (ST) of the columella, which does not fill it completely, a distinct space being left at its anterior and upper margins. At this stage, there is no association between the rim of the fenestra ovalis and the stapes, different to the state observed in early stages.

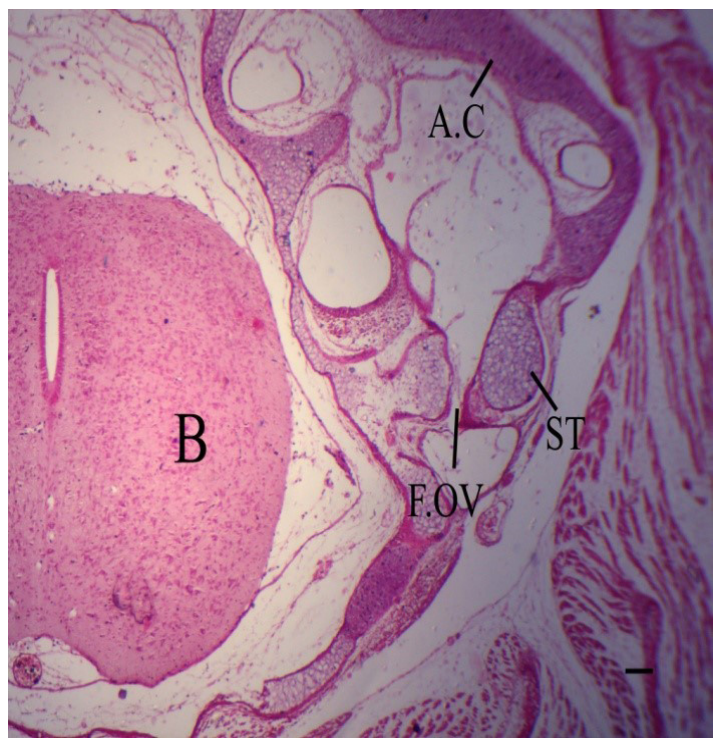

Figure 9. Photomicrograph (H\&E) of a transverse section passing through the auditory region at $9.3 \mathrm{~cm}$ total body length, enlarged fenestra ovalis, it is occluded by columellar foot plate. Scale bars, $75.7 \mu \mathrm{m}$.

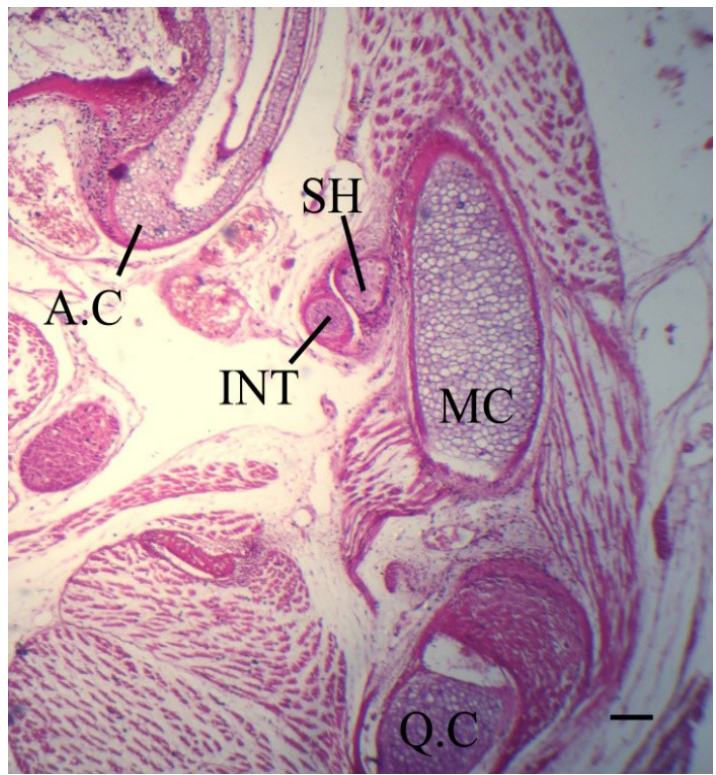

Figure 10. Photomicrograph (H\&E) of a transverse section passing through the auditory region at $9.3 \mathrm{~cm}$ total body length, chondrification to mesenchymal cells which produced by distal end of shaft forming cartilaginous nodule. Scale bars, $75.7 \mu \mathrm{m}$.

In more developing Malpolon embryo (Figure 10, INT), the mesenchymatous cells which produced by the distal end of the shaft becomes cartilaginous in its structure; stylohyal nodule.

The external auditory opening, middle ear cavity, eustachian tube and tympanic membrane are not observed as an Ophidian model. 


\section{Discussion}

The greater part of the work dealing with the sound transmitting apparatus and its development have been done and published on fishes, amphibians and birds. So far as we have been able to ascertain limited investigations have been made on reptilian middle ears of any kind especially in serpentes. Although, the unique way which used by the snakes to transmitte the sound into the inner ear. Our investigation focuses on the development of different structures which share in formation of middle ear as a tool for sound waves transmission. Comparative analysis of sound transmitting apparatus among vertebrate taxa was used to evaluate alternative hypotheses concerning the ecological origin of the distinctive features of the middle ear of snakes. The morphological changes at the level of gross anatomy are paralleled by changes at the cellular level, molecular level and biochemical level. So, further investigations at these levels are recommended.

The morphological description of the sound transmitting apparatus development in Malpolon monsspesulanus has emphasized that it is more or less in accordance with the general pattern of other snakes. In light of our findings, Wever (1978), Young (2003), Friedel et al. (2008), Scanferla and Bhullar (2014) and Dowling (2015) reported that snakes cannot hear. This deduction is supported by the fact that snakes have neither eustachian tube nor tympanum. Also, In Chamaeleo, Holbrookial have no ear drum or middle ear cavity (Tumarkin, 1968). The tympanic membrane in many fossorial (burrowing) and semi-fossorial Lizards, such as the legless Anniella, as well as in other Reptiles, such as the Tuatara, Amphisbaenians, and, of course, Snakes are absent (Tumarkin, 1968; Kaplan, 2014). The middle ear cavity of Crocodilians and Geckos is filled with loose tissue, mostly adipose. The latter condition is similar to our investigation. In contrast with our study which revealed that no eustachian tube is observed, while, Crocodilians have a branching eustachian tube (Kaplan, 2014). Berman and Regal (1967) mentioned that, absence of tympanic membrane and tympanic cavity in the snake due to presence of highly musculature associate with movable quadrate. This highly musculature was detected in our study. In addition, Norris and Lowe (1951) reported that, the depressor mandible muscle displaced forward due to the enlargement of cervicomandibularis muscle lead to close ear opening. Also, Laurin (1996) mentioned that, all Salamanders, Caecilians, some Frogs, Sphenodon, and Snakes are not having a tympanum but can detect pressure waves which transmitted through the substrate.

Anatomically, the columella auris or stapes is homologous in all tetrapods. During evolution; Tumarkin (1968) mention that, the columella is derived from the hyomandibular. In snakes, the hyomandibular loses its suspensory function (autostylic suspension). In the primitive vertebrates and reptiles, the columella derived from the second gill arch (Köppl et al., 2013). Reptiles and birds have one ossicle, homologous to the mammalian stapes (O'Gorman, 2005; Chapman, 2011; Anthwal et al., 2013). The stapedial anlage of human consists of a mesenchymal condensation (Rodríguez-Vázquez, 2005). In addition, Popper et al. (2013) mentioned that, middle ear ossicles are visible as foci of mesenchymal condensation within the embryonic branchial arches. Also in birds, the columellar anlage of Bubulicus ibis appeared as human stapedial anlage (Salah EL-Din and Dakrory, 2015). With agreement, the columellar anlage of Malpolon monsspesulanus appeared as human and birds stapedial anlage, with different in duration between the different species. our research prove that, columella in Malpolon species have only one center of chondrification which seems to be a universal feature in Ophidia. On the other hand, in Lacertilian, Rhynchocephalia and generally in Lizards, the proximal and distal ends of the columella auris have two separate centers of chondrification (Versluys, 1903). De Beer (1937) reported that, the columella auris of lizard arise as a separate cartilage without any connection with the wall of the auditory capsule. Also, in the Andean lizard Ptychoglossus bicolor, the columella auris rests just below the developing otic capsule (Hernández-Jaimes et al., 2012). The previous results are in agreement with our data.

The fenestra ovalis in Malpolon monspessulaus is formed by a process of degeneration in pre-existing cartilage. Similarly, Versluys (1903), in Platydactylus and Gecko observe that the fenestra ovalis is formed by the resorption of the tissue of the originally complete capsular wall. This view is supported by El- Toubi and kamal, 1961 in Ptyodactylus, as well as kamal and Hammouda, 1965 in Psammophis, Eryx and Cerastes respectively. On the other hand, the fenestra ovalis in lizard Lacerta agilisis formed in an unusually different way (De Beer, 1930). In case of Leptodeira hotamboia, the fenestra ovalis in the lateral wall of the cochlear prominence appears an oval shape. In early stage, the foot-plate of the columella almost fills it, and is unclearly separated from the wall. In later stages the fenestra ovalis is much larger than the foot-plate, which does not nearly fill it (Brock, 1929). The reported results are in agreement with our findings.

The stylohyal is a homologue structure to the intercalary cartilage of non Ophidian Squamates (Rieppel, 1980), which is generally involved in the suspension of the quadrate bone in lizards (Oelrich, 1956). The middle ear of snakes is characterized by a particular contact between the distal end of the stapedial shaft with the stylohyal, which is fused to the quadrate bone. The columella auris continues with ceratohyal, and formation of nodule behind these structure which termed stylohyal (Parker, 1879). The distal end of the columella auris (extra-stapedial) remains cartilaginous. Stylohyal becomes lies between the extra-stapedial and the quadrate. It fuses with the inner side of the quadrate and ossified. Möller (1905) shows the development of Parker'sstylohyal at the distal end of the columella auris in Vipera bervus. Also, Brock (1929) report Parker's stylohyal condition in Leptodeira hotamboia. The stylohyal separates from the columella and becomes attach to the quadrate as soon as chondrification process starts. Okajima (1915) recorded that, in Trigonocephalus there is no any connection between the stylohyal and the 
columella auris and considered the first to represent a process of the quadrate. Our investigation is in accordance with Parker's stylohyal.

Generally, the development of an organism is a modification of its ancestors' ontogenies according to macroevolution (Futuyma, 1998), and embryology provides testable confirmations and predictions about macroevolution (Gilbert, 1997). So, embryology and developmental studies provide an independent body of evolutionary evidence. The intimate relationship between the evolution and embryogenesis was emphasized by Sienknecht (2013) through making a study on development of middle ear. The evolution of the middle ear in tetrapods is well documented in the fossil record (Tucker et al., 2004). Manley and Clack (2004) and Manley (2010) recorded general reviews about the evolution of the middle ear in the vertebrates. The middle ear of land vertebrates presents one of the most remarkable and best documented examples of functional transformation in vertebrate evolution (Carroll, 1987; Lombard and Bolt, 1979). Evolution of the ear is primarily a result of adaptation to terrestrial environments, brought about by selective pressures to sense noises and vibrations in the environment. Allowed the detection of predators and prey, eventually led to communication between individuals. The evolution of the middle ear illustrates the changes in functions that can occur for a single structure (hyomandibular bone/cartilage $\rightarrow$ columella $\rightarrow$ stapes. Feeding $\rightarrow$ respiration $\rightarrow$ feeding $\rightarrow$ hearing)

\section{Conclusions}

The data were presented in this investigation document the spatiotemporal events leading to morphogenesis of different sound transmitting apparatus. These data facilitate future functional studies, elucidation of the molecular mechanisms of sound transmitting apparatus and diagnosis of diseases that may infect them.

\section{Acknowledgements}

This paper was supported by Zoology Department, Faculty of Science, Cairo University.

\section{References}

ANTHWAL, N., JOSHI, L. and TUCKER A.S., 2013. Evolution of the mammalian middle ear and jaw adaptations and novel structures. Journal of Anatomy, vol. 222, pp. 147-160. http:// dx.doi.org/10.1111/j.1469-7580.2012.01526.

BERMAN, D.S. and REGAL, P.J., 1967. The loss of the ophidian middle ear. Evolution, vol. 21, no. 3, pp. 641-643. http://dx.doi. org/10.1111/j.1558-5646.1967.tb03418.x.

BERNHARD, G., 1971. Crzaimek's Animal Life Encyclopedia. New York: Van Nostrand Company.

BROCK, G.T., 1929. On the development of the skull of leptodeirahotamboia. Quarterly Journal of Microscopical Science, vol. s2, no. 73, pp. 289-331. http://dx.doi.org/10.1038/163106b0.
CARROLL, R.L., 1987. Vertebrate palaeontology and evolution. New York: Freeman.

CHAPMAN, S.C., 2011. Can you hear me now? Understanding vertebrate middle ear development. Frontiers in Bioscience, vol. 16, no. 1, pp. 1675-1692. http://dx.doi.org/10.2741/3813.

CHRISTENSEN, C. B., CHRISTENSEN-DALSGAARD, J., BRANDT, C. and MADSEN, P. T., 2012. Hearing with an atympanic ear: good vibration and poor soundpressure detection in the royal python, Python regius. Journal of Experimental Biolology, vol. 215, pp. 331-342. http://dx.doi.org/10.1242/jeb.062539.

CHRISTENSEN, C.B., CHRISTENSEN-DALSGAARD, J. and MADSEN, P.T., 2015. Hearing of the African lungfish (Protopterusannectens) suggests underwater pressure detection and rudimentary aerial hearing in early tetrapods. The Journal of Experimental Biology, vol. 218, no. Pt 3, pp. 381-387. PMid:25653420. http://dx.doi.org/10.1242/jeb.116012.

CHRISTIAN, B.C., HENRIK, L., CHRISTENSEN-DALSGAARD, J., MICHAEL, P. and PETER, T.M., 2015. Better than fish on land? Hearing across metamorphosis in salamanders. Proceedings of the Royal Society of Biology, vol. 282, no. 1802, pp. pii-20141943. http://dx.doi.org/10.1098/rspb.2014.1943.

DE BEER, G.R., 1930. The early development of the chondrocranium of the lizard. The Quarterly Journal of Microscopical Science, vol. 73, pp. 707-739. http://dx.doi.org/10.2108/zsj.16.803.

DE BEER, G.R., 1937. The development of the vertebrate skull. Chicago: University of Chicago Press.

DOWLING, H.G., 2015 [viewed 24 June 2015]. Reptilia: hearing [online]. Available from: http://www.britannica.co.uk

EL-TOUBI, M. R., KAMAL, A. M. and ZAHER, M. M., 1973a. The development of the chondrocranium of the snake, Malpolon monspessulana. I. The early and intermediate stages. Acta Anatomica, vol . 85, pp. 275-299.

EL-TOUBI, M. R., KAMAL, A. M. and ZAHER, M. M., 1973 b. The development of the chondrocranium of the snake, Malpolon monspessulana. II. The fully formed stage. Acta Anatomica, vol. 85 , pp. 593.

FRIEDEL, P., YOUNG, B. A. and VAN HEMMEN, J. L., 2008. Auditory localization of ground-borne vibrations in snakes. Physical Review Letters, vol. 100, no. 4, pp. 048701. http://dx.doi. org/10.1037/0735-7036.122.1.35.

FUTUYMA, D., 1998. Evolutionary biology. 3rd ed. Sunderland: Sinauer Associates.

GILBERT, S.F., 1997. Developmental biology. 5th ed. Sunderland: Sinauer Associates.

GOLDBY, F., 1925. The development of the columella auris in the crocodilian. Journal of Anatomy, vol. 59, pp. 301-325. http:// dx.doi.org/10.1080/00445096.1974.11448520.

HERNÁNDEZ-JAIMES, C., JEREZ,A. and RAMÍREZ-PINILLA, M.P., 2012. Embryonic development of the skull of the Andean lizard Ptychoglossus bicolor (Squamata, Gymnophthalmidae). Journal of Anatomy, vol. 221, no. 4, pp. 285-302. PMid:22881276. http://dx.doi.org/10.1111/j.1469-7580.2012.01549.x.

KAMAL, A.M. and HAMMOUDA, H.G., 1965. The columella of the snake Psammophis sibilans. Anatomischer Anzeiger, vol. 116, pp. 124-138. http://dx.doi.org/10.1111/j.1463-6395.1965.tb00731. 
KAPLAN, M., 2014 [viewed 1 January 2014]. Reptile hearing. brief overview of ear structures and function... Simplified. Really [online]. Available from: http://www.anapsid.org/reptilehearing.html

KNIGHT, K., 2012. Snakes hear through skull vibration. Cambridge: The Company of Biologists Ltd.

KUNDRÁT, M., 2009. Primary chondrification foci in the wing basipodium of Struthio camelus with comments on interpretation of autopodial elements in Crocodilia and Aves. Journal of experimental zoology. Part B, Molecular and Developmental Evolution, vol. 312B, pp. 30-41. PMID: 18942113. http://dx.doi. org/10.1002/jez.b.21240.

KÖPPL, G., MANLEY, G.A., POPPER, A.N. and FAY, R.R., 2013. In sights from comparative hearing research. Springer: New York.

LAURIN, M., 1996. Hearing in stegocephalians. Paris: Muséum National d'Histoire Naturelle. Tree of Life web project.

LOMBARD, R. E. and BOLT, J. R., 1979. Evolution of the tetrapod ear: an analysis and reinterpretation. Biological Journal of the Linnean Society, vol. 11, pp. 19-76. http://dx.doi. org/10.3158/2158-5520-5.1.59.

MANLEY, G.A. and CLACK, J.A., 2004. An outline of the evolution of vertebrate heaing organs. New York: Springer.

MANLEY, G.A., 2010. An evolutionary perspective on middle ears. Hearing Research, vol. 263, no. 1-2, pp. 3-8. PMid:19786082. http://dx.doi.org/10.1016/j.heares.2009.09.004.

MÖLLER, W., 1905. Zurkenntnis der Entwicklung des Gehörknöchelchensbei der kreuzotter und der Ringelnatter, nebstBemerkungenZurNeurologiedieserSchlangen. Archiv für Mikroskopische Anatomie, vol. 65, pp. 439-497. http://dx.doi. org/10.1056/NEJMoa1114885.

NORRIS, K. S. and LOWE, C. H. A., 1951. Study of the osteology and musculature of Phrynosomemcalli pertinent to its systematic position. Bulletin Chicago Academy of Sciences, vol. 9, pp. 117-125. http://dx.doi.org/10.1894/0038-4909-57.4.435.

O'GORMAN, S., 2005. Second branchial arch lineages of the middle ear of wild type and Hoxa2 mutant mice. Developmental Dynamics, vol. 234, no. 1, pp. 124-131. PMid:15861402. http:// dx.doi.org/10.1002/dvdy.20402.

OELRICH, T.M., 1956. The anatomy of the head of Ctenosaurapectinata (Iguanidae). Misc Pub MusZoolUniv Michigan., vol. 94, pp. 1-122. http://dx.doi.org/10.1111/j.1469-7998.1984.tb02376.

OKAJIMA, K., 1915. BeiträgezurEntwicklungsgeschichte und Morphologie des Gehörknöchelchensbei den Schlangen. Anatomical Hefete, vol. 53, pp. 385-417. http://dx.doi.org/10.1093/ndt/gfl118.

PARKER, W.S., 1879. On the structure and development of the skull in the common snake (Tropidontus natrix). Philosophical Transactions of the Royal Society, vol. 169, pp. 385-417. http:// dx.doi.org/10.1098/rstl.1878.0012.
POPPER, A. N., FAY, R. R. and PURIA, S., 2013. The middle ear. New York: Springer-Verlag.

RIEPPEL, O., 1980. The sound-transmitting apparatus in primitive snake and its phylogenetic significance. Zoomorphology, vol. 96, no. 1-2, pp. 45-62. http://dx.doi.org/10.3158/2158-5520-5.1.99.

RODRÍGUEZ-VÁZQUEZ, J.F., 2005. Development of the stapes and associated structures in human embryos. Journal of Anatomy, vol. 207, no. 2, pp. 165-173. PMid:16050903. http:// dx.doi.org/10.1111/j.1469-7580.2005.00441.x.

SALAH EL-DIN, E. Y. and DAKRORY, A. I., 2015. Basic anatomical and embryological description of early middle ear in Cattele egrett; Bubulicus ibis. Sylwan, vol. 159, no. 4, pp. 56-71.

SCANFERLA, A. and BHULlAR, B., 2014. Postnatal development of the Skull of Dinilysiapatagonica (Squamata-Stem Serpentes). The Anatomical Record, vol. 297, no. 3, pp. 560-573. PMid:24493375. http://dx.doi.org/10.1002/ar.22862.

SIENKNECHT, U.J., 2013. Developmental origin and fate of middle ear structures. Hearing Research, vol. 301, pp. 19-26. PMid:23396272. http://dx.doi.org/10.1016/j.heares.2013.01.019.

THEWISSEN, J.G.M., NUMMELA, S., THEWISSEN, J.G.M. and NUMMELA, S., 2008. Sensory evolution on the threshold: adaptations in secondarily aquatic vertebrates. Berkeley: University of California Press.

TUCKER, A.S., WATSON, R.P., LETTICE, L.A., YAMADA, G. and HILL, R.E., 2004. Bapx1 regulates patterning in the middle ear: altered regulatory role in the transition from the proximal jaw during vertebrate evolution. Development, vol. 131, no. 6, pp. 1235-1245. PMid:14973294. http://dx.doi.org/10.1242/dev.01017.

TUMARKIN, A., 1968. Evolution of the auditory conducting apparatus in terrestrial vertebrayes. In: A.S. REUCK and J. KINGHT, eds. Hearing mechanisn in vertebrates. USA: Ciba Foundation, pp. 18-37. http://dx.doi.org/10.1002/9780470719657.ch3.

VERSLUYS, J. R. J., 1903. Entwicklung der Columella auris bei den Lacertiliern. Ein Beitragzur Kenntnis der schalleitenden Apparat und des Zungen bein bogens bei den Sauropsiden. Zoologische Jahrbücher, vol. 1, pp. 107.

WEVER, E.G., 1978. The reptile ear, its structure and function. Princeton: Princeton University Press.

YOUNG, B. A., 2003. Snake bioacoustics: toward a richer understanding of the behavioral ecology of snakes. Quarterly Review of Biology, vol. 78, pp. 303-325. http://dx.doi. org/10.2994/057.004.0104.

ZYGA, L., 2008 [viewed 13 February 2008]. Desert snake hears mouse footsteps with its jaw [online]. USA: Phys Org. Available from: https://phys.org/news/2008-02-snake-mousefootsteps-jaw.html 